J. Clin. Chem. Clin. Biochem.

Vol. 21, 1983, pp. 829-833

\title{
The Influence of Tracers on Insulin Binding to Human Erythrocytes
}

\author{
By R. Hepp, H. E. Meyer \\ Biochemische Abteilung, Diabetes Forschungsinstitut an der Universität Düsseldorf
}

\section{F. Peters}

Abteilung Biophysikalische Chemie, Medizinische Hochschule Hannover

Waltraud Paßlack and H. Reinauer

Biochemische Abteilung, Diabetes Forschungsinstitut an der Universität Düsseldorf

(Received April 7/July 5, 1983)

Dedicated to Prof. Dr. med. Karl Oberdisse on the occasion of his 80th birthday

Summary: We studied insulin binding to human erythrocytes using two different ${ }^{125}$ I-insulin-tracers. Erythrocytes of 8 normal subjects were examined using [mono- ${ }^{125}$ I-(Tyr A 14)]insulin as tracer. Three of these erythrocyte preparations were examined simultaneously using [ $\left.{ }^{125} \mathrm{I}\right]$ insulin, which was randomly iodinated by the chloramine-T-method.

Data were analysed by a computerized non-linear least-squares procedure both on the basis of one and two class receptor models. Only the one class receptor model yielded consistent results. When the two class receptor model was applied the low affinity branch of the Scatchard plot was not reproducible. On the basis of the one class receptor model the number of receptor sites was lower $\left(R_{0}=0.046 \pm 0.006 \mathrm{nmol} / \mathrm{l}\right.$ equivalent to $6.3 \pm 0.8$ receptors/erythrocyte) with [mono- ${ }^{125} \mathrm{I}$-(Tyr A 14)] insulin as compared to [ $\left.{ }^{125} \mathrm{I}\right]$ insulin randomly iodinated by the chloramine- $T$ method $\left(R_{0} \equiv 0.070 \pm 0.008 \mathrm{nmol} / 1\right.$ equivalent to $9.6 \pm 1.1$ receptors/erythrocyte). Conversely, the affinity of the $\left[\right.$ mono ${ }^{125} \mathrm{I}-($ Tyr A 14$\left.)\right]$ insulin was higher $\left(\mathrm{K}_{\mathrm{a}}=2.6 \pm 0.3 \times 10^{9} \mathrm{I}\right.$. $\mathrm{mol}^{-1}$ vs. $\left.1.9 \pm 0.2 \times 10^{9} \mathrm{I} \cdot \mathrm{mol}^{-1}\right)$.

\section{Der Einfluß des Tracers auf die Insulinbindung an Erythrocyten des Menschen}

Zusammenfassung: Die İnsulinbindung an Human-Erythrocyten wurde mit zwei verschiedenen [ ${ }^{125}$ I]Insulinpräparaten gemessen. Die Erythrocytenrezeptoren von 8 Normalpersonen wurden mit [Mono- ${ }^{125}$ I-(Tyr A 14)]Insulin als Tracer bestimmt. Drei dieser Erythrocytenpräparationen wurden gleichzeitig mit [ $\left.{ }^{125} \mathrm{I}\right]$ Insulin, das nach der Chloramin-T Methode hergestcllt war, auf ihre Insulinbindung untersucht.

Die Meßdaten wurden mit Hilfe eines Computerprogramms nach einer nicht-linearen Regression ausgewertet; dābeei wurden sowohl eine Bindungsklasse als auch zwei Bindungsklassen zu Grunde gelegt. Nur das einklassige Bindungsmodell lieferte zuverlässige Werte. Bei Annahme eines zweiklassigen Bindungsmodells ergaben sich für den niederaffinen Bindungsast in der Scatchard Auftragung keine zuverlässigen Werte. Die Auswertung nach dem einklassigen Bindungsmodell ergab mit [Mono-125I-(Tyr A 14)]Insulin als Tracer eine niedrigere Rezeptorzahl $\left(R_{0}=0,046 \pm 0,006 \mathrm{nmol} / 1\right.$ entsprechend 6,3 $\pm 0,8$ Rezeptoren/Erythrocyt) verglichen mit [ $\left.{ }^{125} \mathrm{I}\right]$ Insulin, iodiert nach der Chloramin-T-Methode $\left(R_{0}=0,070 \pm 0,008 \mathrm{nmol} / \mathrm{l}\right.$ entsprechend 9.6 $\pm 1,1$ Rezeptoren/Erythrocyt). Umgekehrt war die Affinität des [Mono- ${ }^{125} I-\left(T y r\right.$ A 14)]Insulin höher $\left(K_{\mathrm{a}}=\right.$ $2,6 \pm 0,3 \times 10^{9} 1 \cdot \mathrm{mol}^{-1}$ vs. $\left.1,9 \pm 0,2 \times 10^{9} 1 \cdot \mathrm{mol}^{-1}\right)$. 


\section{Introduction}

Insulin binding studies to human erythrocytes have been widely used since they were first described by Gambhir et al. (1). The obtained data were usually presented as displacement curves and Scatchard plots.

The Scatchard plots described were often curvilinear and there was an argument in the literature as to the reason for this shape. Different concepts are under discussion. Kahn et al. (2) suggested two populations of receptors whereas De Meyts et al. (3) attributed the curvilinear nature of the Scatchard plot to negative cooperativity between homogenous receptor sites. In some cases the second class could be explained as an artifact due to an incorrectly determinated unspecific binding (4).

To our knowledge only one of the authors (5) studying insulin binding to erythrocytes has so far considered the influence of their tracers on their results. We therefore stùdied insulin binding to human erythrocytes using two different [ ${ }^{125}$ I] insulin-tracers. [Mono- ${ }^{125}$ I-(Tyr A 14)]insulin (Novo Research Institute) is a purified isomer which is exclusively iodinated in the Tyr A 14 position. In contrast $\left[{ }^{125} I\right]$ insulin labelled by the chloramine- $\mathrm{T}$ method is a mixture of isomers (e.g. Tyr A 14, Tyr A 19, etc.) and contains diiodinated tyrosines as well (6).

\section{Materials and Methods}

Blood $(10-20 \mathrm{ml})$ was taken from 8 metabolically healthy volunteers after an overnight fast.

Novo Research Institute: 1. Porcine [mono- ${ }^{125}$ I-(Tyr A 14)insulin, spec. radioactivity $6.77 \mathrm{MBq} / \mu \mathrm{g}$, 2. Porcine mono-component insulin.

Hoechst AG, Frankfurt, West Germany: Porcine [ $\left.{ }^{125} I\right]$ insulin, spec. radioactivity $5.55 \mathrm{MBq} / \mu \mathrm{g}$.

Merck AG, Darmstadt, West Germany: Hepes(N-2-hydroxyethylpiperazine-N'-2-ethanesulphonic acid), $\mathrm{MgCl}_{2}, \mathrm{CaCl}_{2}$, dextrose, $\mathrm{NaCl}$, tris (tris(hydroxymethylaminomethane)), $\mathrm{KCl}$.

Fluka AG, Buchs SG, Switzerland: EDTA.

Serva Feinbiochemica, Heidelberg, West Germany: Bovine serum albumin.

W \& R Balston Ltd: Whatman 1 PS filter.

Schuchardt, D-8010 Hohenbrunn, West Germany: Dibutyl phthalate.

Beckman: Microfuge B

Sorvall: Superspeed RC 2 B

Berthold: LB MAG 5 io gamma counter

Coulter: cell counter

Assay Buffer. Our assay buffer was buffer $G$ as described by Gambhir et al. (1), except that we used $10 \mathrm{~g} / \mathrm{l}$ bovine serum albumin.

\section{Preparation of erythrocytes}

The erythrocytes were separated by a method described by Bcutler et al. (7), with some minor modifications.

Blood was collected into heparinized tubes, passed through a column of microcrystalline cellulose mixed $1: 1$ with alpha-cellulose in $9 \mathrm{~g} /$ saline. The number of red blood cells was counted in a coulter counter. The erythrocytes were then iwashed three times $\left(400 \mathrm{~g}, 10 \mathrm{~min}, 4^{\circ} \mathrm{C}\right)$, first with $9 \mathrm{~g} / \mathrm{l}$ saline, then with buffer $\mathrm{G}$ without bovine serum albumin and last with buffer $G$ containing bovine serum albumin. Finally, the erythrocytes were resuspended to a concentration of 3.5 to $5.5 \times 10^{12} /$. Both before and after the preparation red blood cells, reticulocytes and leukocytes were counted. Leukocyte counts were always in the range of a cell free control solution.

Blood glucose and serum insulin concentrations were determined routinely.

\section{Binding studies}

Binding studies were performed as described elsewhere (1), with some minor modifications.

Briefly, $400 \mu \mathrm{l}$ cell suspension, $13.3 \mathrm{pmol} / \mathrm{h}$ or $50 \mathrm{pmol} /{ }^{125} \mathrm{I} \mathrm{la-}$ belled insulin and various amounts of unlabelled insulin $(0-1$ $\mu \mathrm{mol} / \mathrm{l})$ in a total volume of $500 \mu \mathrm{l}$ were incubated at $15^{\circ} \mathrm{C}$ for 210 minutes.

After incubation, $150 \mu \mathrm{l}$ aliquots were transfered to three chilled microfuge tubes that contained $150 \mu \mathrm{l}$ buffer $G$ and $100 \mu$ dibutyl phthalate. After centrifugation, the tubes were kept in a refrigerator at $-80^{\circ} \mathrm{C}$ for 30 minutes. The tips of the tubes containig the cell pellets were then cut and radioactivity was counted in a gamma counter.

\section{Data analysis}

Data were analyzed by a computerized weighted nonlinear leastsquares procedure using the displacement curves (4). Both oñe class and two class receptor models were applied. Data are pres= ented in two ways.

Firstly, specific binding of insulin is plotted as a function of the logarithm of total insulin concentration. Non-specific binding was defined as $\left[{ }^{125} \mathrm{I}\right]$ insulin binding in the presence of $1 \mu \mathrm{mol} / 1$ unla= belled insulin. This value was varied during the regression analysis and small differences appeared depending on the assumption of the one or two classes of binding sites. The amount of insulin spe= cifically bound was normalized to a red cell concentration of $4.4 \times$ $10^{12} /$.

Secondly, the bound to free ratio $(\bar{B} / F)$ of insulin is plotted as a function of bound insulin (B) using the results of the best fit (Scatchard plot). The number of receptor sites per cell was calculatẹ on the basis of a one class model.

\section{Results}

\section{Specific insulin binding}

Specific insulin binding at $13.3 \mathrm{pmol} / \mathrm{1}\left[\mathrm{mono}-{ }^{125} \mathrm{I}-\right.$ (Tyr A 14)]insulin varied from 0.09 to $0.13(n=20$, mean $\pm S D=0.116 \pm 0.012$ ) in normal subjects (fig. 1).

Specific insulin binding at the same concentration of randomly labelled [ $\left.{ }^{125} I\right]$ insulin was found to be higher when examined simultaneously in three healthy subjects $(n=6$, double aşays, mean $\pm S D$ 
$=0.119 \pm 0.013$ vs. $0.107 \pm 0.015$, fig. 2 ). Both healthy and diabetic subjects showed reproducible results with [mono- ${ }^{-125}$ ]-(Tyr A 14)]insulin, even in diabetic patients with extremely low binding activity (fig. 3).

\section{Analysis of displacement curves}

\section{One class receptor model}

On direct comparison we found that [mono- ${ }^{125} \mathrm{I}-(\mathrm{Tyr}$ A 14)] insulin detected a lower number of receptor

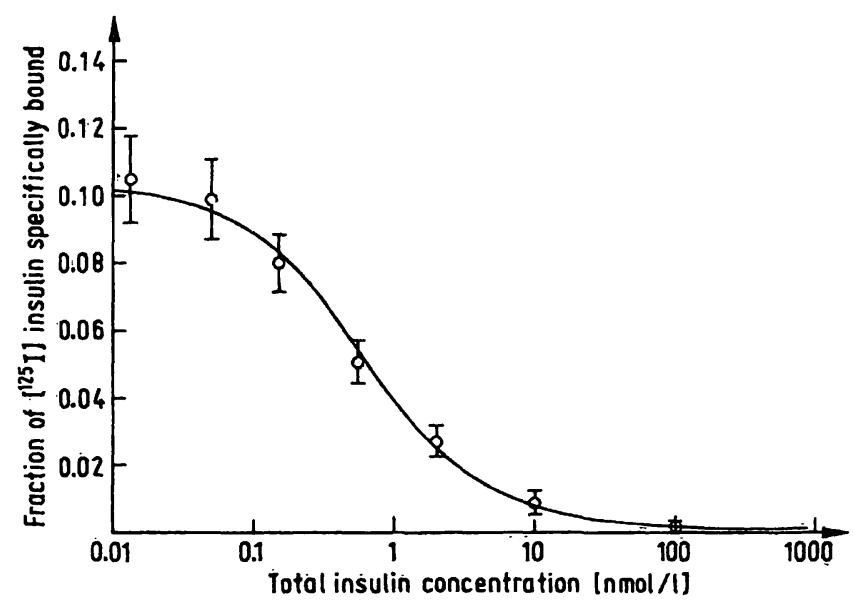

Fig. 1. Fraction of [mono- ${ }^{125} \mathrm{I}$-(Tyr A 14)] insulin specifically bound to human erythrocytes is plotted against the concentration of insulin. Blood was taken from 8 healthy subjects, $20-35$ years old. A total of 20 experiments were carried out. Nonspecific binding was defined as the radioactivity. measured in the cell pellet in the presence of 1 $\mu \mathrm{mol} / /$ native insulin. The results were normalized to a red cell concentration of $4.4 \times 10^{12} / 1$. Each point is the mean of 20 experiments $\pm 1 \mathrm{SD}$.

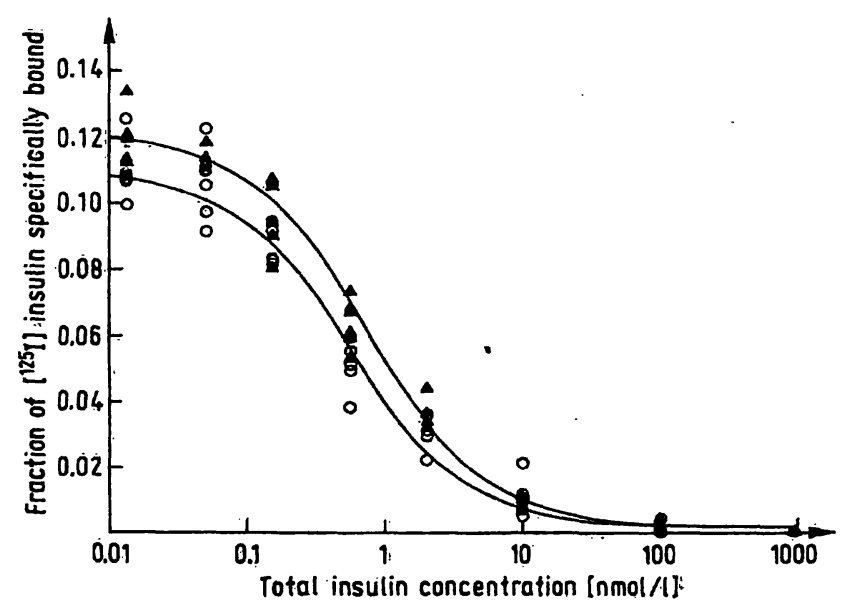

Fig. 2. Insulin binding to the erythrocytes of 3 normal subjects. Circles represent data obtained with [mono-125]-(Tyr A 14)]insulin, triangles stand for conventional $\left[{ }^{125} \mathrm{I}\right]$ insulin. The best fit curves are shown for either group assuming an one class model. sites $\left(R_{0}=0.046 \pm 0.006 \mathrm{nmol} / \mathrm{l}\right)$ but showed a higher affinity $\left(\mathrm{K}_{\mathrm{a}}=2.6 \pm 0.3 \times 10^{9} \mathrm{l} \cdot \mathrm{mol}^{-1}\right)$ than randomly labelled [ $\left.{ }^{125} \mathrm{I}\right]$ insulin $\left(\mathrm{R}_{\mathrm{n}}=0.070 \pm 0.008\right.$ $\mathrm{nmol} / \mathrm{l} ; \mathrm{K}_{\mathrm{a}}=1.9 \pm 0.2 \times 10^{9} \mathrm{l} \cdot \mathrm{mol}^{-1}$; fig. 4). The measured data are in good agreement with the one class model.

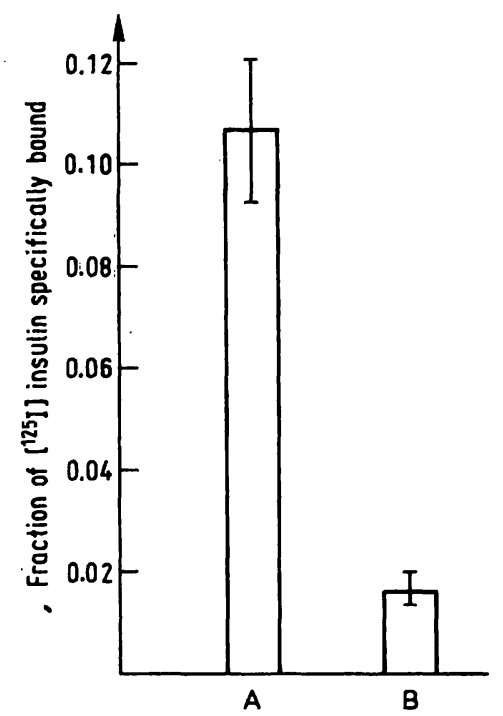

Fig. 3. Reproducibility of the measured specifically bound [mono- ${ }^{125}$ I-(Tyr A 14) ]insulin.

A) data of a 25 year old healthy male, who was examined 7 times on 4 different days over a period of 4 months. B) data of a 20 year old diabetic female with extremely low insulin binding. She was examined 7 times under the same conditions. Means \pm 1 SD are shown.

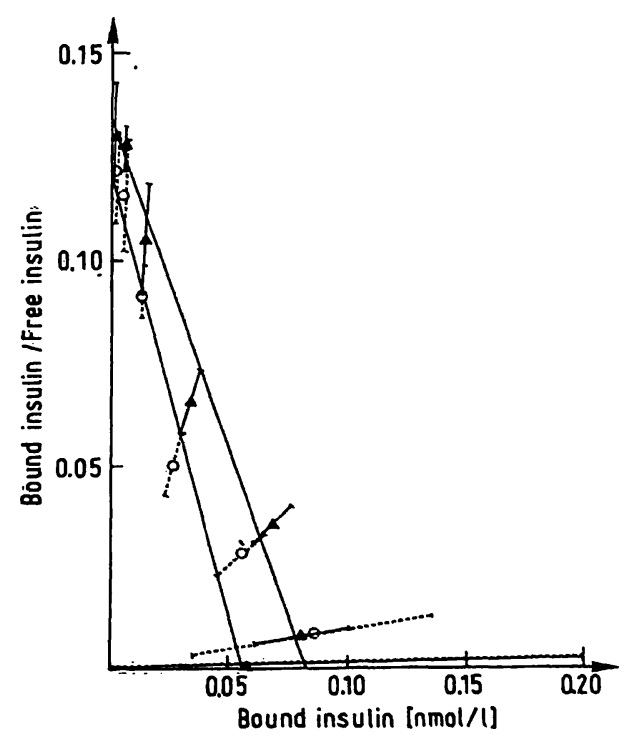

Fig. 4. Presentation of the binding data according to Scatchard calculated with the nonlinear regression method using the one-class receptor model. Circles represent data obtained with (mono- ${ }^{125}$ I-(Tyr A 14) ]insulin, triangles stand for conventional | ${ }^{125} 1$ |insulin. Data are from the experiments shown in figure 2 . 


\section{Two class receptor model}

When the two class receptor model was applied (fig. 5) the low affinity part of the plot was not reproducible. In the same individuals under identical conditions its intercept with the abscissa, and thus the number of receptor sites, could vary by up to $400 \%$ (fig. 6).

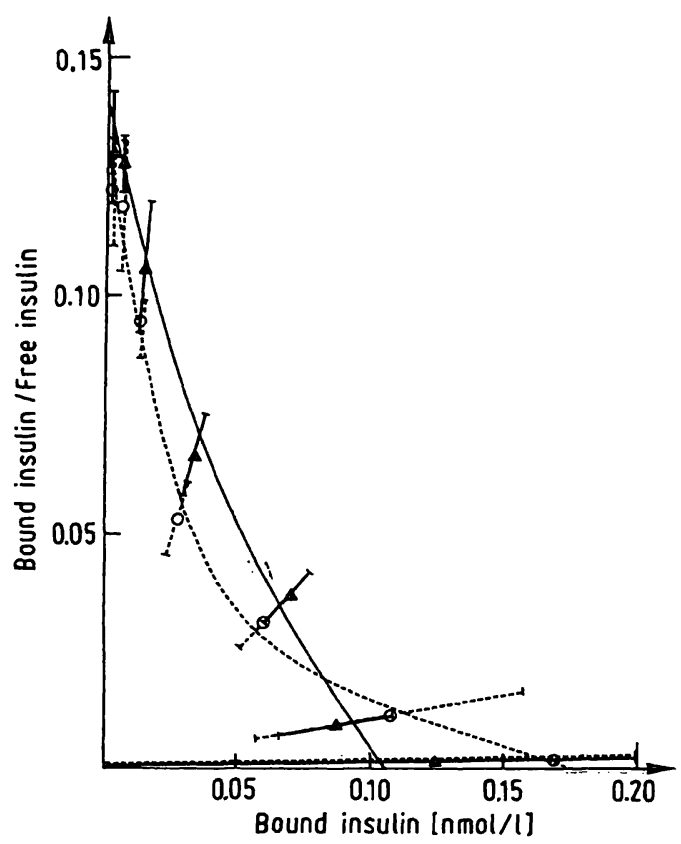

Fig. 5. Scatchard plots on the basis of the two-class receptor model. Same data as in figure 2.

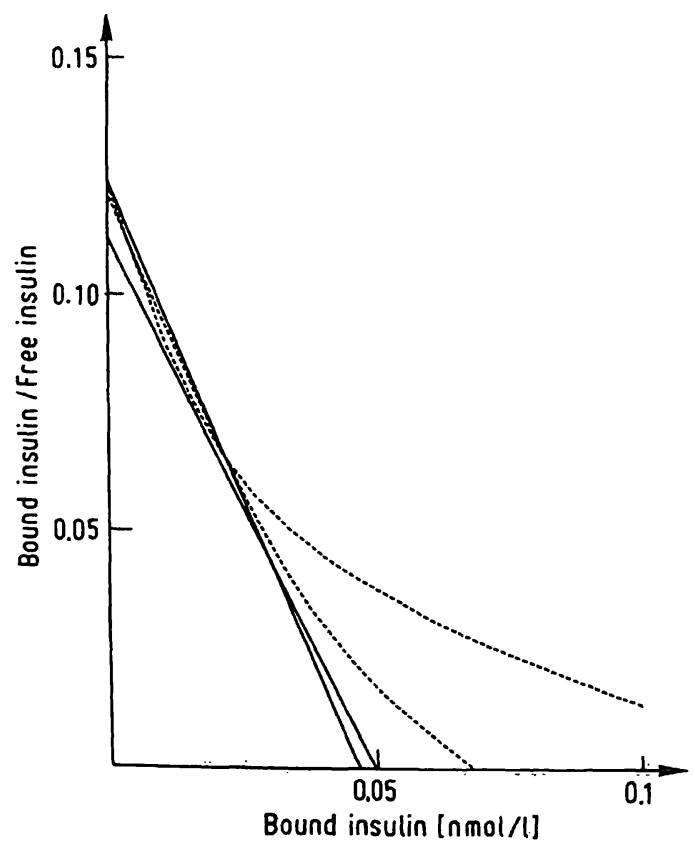

Fig. 6. Scatchard plots of a healthy volunteer. Assays were performed in duplicate and [mono- ${ }^{125}$ I-(Tyr A 14)]insulin was used. The continuous lines were calculated on the basis of the one-class receptor model, the broken lines represent the two-class receptor model. The low affinity branches of the Scatchard plots were not reproducible.

\section{Discussion}

Insulin binding studies to erythrocytes have been used in clinical trials throughout the world over recent years $(5,8,9,10,11)$. Unfortunately the authors used labelled insulin of different origin and quality. So far only one group has considered the influence of the quality of their tracers on the binding data (5).

In this study (5), the values given for the high affinity binding constants (a 50-fold difference between the two tracers) and for the high affinity binding sites (210-230 receptors/erythrocyte) are quite different from the values found in the present study, and those found by others $(11-14)$.

We could demonstrate that the quality of the tracèr has a strong influence on the results, but in contrast to the study by Schlüter et al. (5), the differences of the affinity constants and receptor numbers are much smaller. We cán explain these differences as observed in our experiments by different degrees of purity of tracers. The chloramine-T-method, which is commonly used to iodinate insulin, produces 4 isomers (Tyr A 14, Tyr A 19, Tyr B 16 and Tyr B 26) as well as diiodinated tyrosines.

These isomers have different affinities to the insulin receptor. The better these isomers can be separated and purified the more reliable will be the results (15). Different methods used by the manufacturers to determine specific radioactivity may be another explanation. Certainly it is recommendable to use only freshly labelled insulin as tracers, since the rate of decay of the binding activity may not closely correlate with the rate of decreasing radioactivity. In our study, the low affinity part of the Scatchard plot was not reproducible with both tracers. We regard this as an argument against the two class receptor concept.

\section{Acknowledgements}

Special thanks are due to the normal volunteers $M$. Rutschmann, N. Bernd, H. Hoff, L. Bohne, H. Kellinghaus, Kohlenburg and $M$. Börries for their blood samples. For the help during the comparative study we give thanks to the students $C$. Samerski, $J$ : Meyercord, S. Wegener, S. Brock, U. Walldorf, M. Voigtländer, J. Schumacher and $M$. Krevet. We wish to thank Dr. L. Kuehn for reading the manuscript.

This work was supported by the Deutsche Forschungsgemeinschaft (SFB 113), the Ministerium für Wissenschaft und Forschung des Landes Nordrhein Westfalen and the Bundesministeriụm für Familie, Jugend und Gesundheit. 


\section{References}

1. Ghambir, K. K., Archer, J. A. \& Bradley, C. J. (1978) Diabetes 27, 701-708.

2. Kahn, C. R., Freychet, P., Roth, J. \& Neville, D. M. Jr. (1974) J. Biol. Chem. 249, 2249-2257.

3. De Meyts, P., Roth, J., Neville, D. M. Jr., Gavin, J. R. III \& Lesniak, M. A. (1973) Biochem. Biophys. Res. Commun. 55, $154-161$.

4. Peters, F. \& Pingoud, V. A. (1982) Biochim. Biophys. Acta $714,442-447$

5. Schlüter, K. J., Petersen, K.-G., Burmeister, P. \& Kerp, L. (1982) In: Neue Insuline. 1. Internationales Symposium (Petersen, K.-G., Schlüter, K. J. \& Kerp, L., ed.) Freiburger Graphische Betriebe, pp. 118-124.

6. Linde, Susanne, Hansen, B., Sonne, O., Holst, J. J. \& Gliemann, J. (1981) Diabetes 30, 1-8.

7. Beutler, E., West, C. \& Blume, K.-G. (1976) J. Lab. Clin. Med. 88, 328-333.

8. Kappy, M. S. \& Plotnick, L. (1980) J. Clin. Endocrinol. Metab. 51, 1440-1446.

9. Wachslicht-Rodbard, H., Gross, H. A., Rodbard, D., Ebert, M. H. \& Roth, J. (1979) N. Engl. J. Med. 300, 882-887.

10. Robinson, T. J., Archer, J. A., Ghambhir, K. K., Hollis, V. W. Jr., Carter, L. \& Bradley, C. (1979) Science 205, 200202.

11. De Pirro, R., Fusco, A., Lauro, R., Testa, I., Feretti, F. \& De Martinis, C. (1980) Diabetes 29, 96-99.

12. Dwenger, A., Mitzkat, H.-J., Holle, W., Tost, P. \& Trautschold, I. (1982) J. Clin. Chem. Clin. Biochem. 20, 273-279.

13. Holle, A., Mangels, W., Dreyer, M., Kühnau, J. \& Rüdiger, H. W. (1981) N. Engl. J. Med. 305, 563-566.

14. Dons, R. F., Ryan, J., Gorden, P. \& Wachslicht-Rodbard, H. (1981) Diabetes 30, 896-902.

15. Sonne, O., Linde, S., Larsen, T. R. \& Gliemann, J. (1983) Hoppe-Seyler's Z. Physiol. Chem. 364, 101-110.

Dr. rer. nat. Helmut E. Meyer

Biochemische Abteilung des

Diabetes-Forschungsinstituts

Auf'm Hennekamp 65

D-4000 Düsseldorf 
t

。

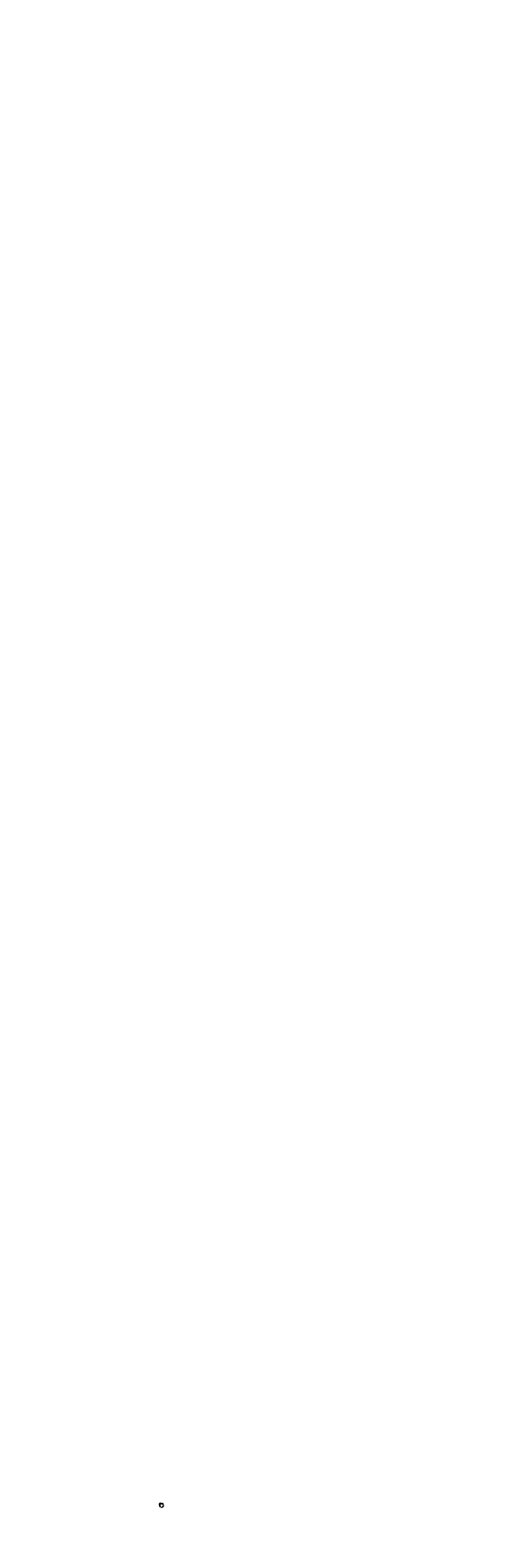

.

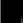

